\title{
GENERA NYAMUK (CULICIDAE) DALAM KANDANG SEBAGAI VEKTOR PENYAKIT JAPANESE ENCEPHALITIS PADA TERNAK BABI DI DESA TOLOK KECAMATAN TOMPASO KABUPATEN MINAHASA
}

\author{
Dave R. Lengkey, A. J. Podung, M. J. Nangoy*, M. Th. Lapian
}

Fakultas Peternakan Universitas Sam Ratulangi Manado

\begin{abstract}
ABSTRAK
Penelitian ini bertujuan untuk mengetahui keragaman dan kepadatan populasi serta waktu aktivitas nyamuk (Culicidae) di kandang babi. Penelitian ini dilaksanakan di Desa Tolok Kecamatan Tompaso Kabupaten Minahasa selama 2 (dua) bulan pada 2 (dua) lokasi kandang yaitu kandang I (jarak kandang dengan rumah kurang dari $10 \mathrm{~m}$ ) dan kandang II (lebih dari $50 \mathrm{~m}$ ). Penelitian ini menggunakan metode observasi dengan cara mengumpulkan sampel nyamuk setiap 2 (dua) jam pada Light trap yang ditempatkan setiap kandang. Pengumpulan sampel dilakukan mulai jam 18.00-06.00, pada setiap lokasi dilakukan ulangan sebanyak 3 (tiga) kali dengan interval waktu dua minggu. Sampel yang terkumpul di identifikasi dan dihitung. Hasil penelitian diperoleh keragaman nyamuk kandang I dan II masing-masing ditemukan 3 genus yaitu Culex, Anopheles dan Armigeres. Kepadatan populasi kandang I ditemukan 128 individu nyamuk yang terdiri dari Culex 104 ekor, Anopheles 20 ekor, dan Armigeres 4. Kandang II ditemukan 46 individu nyamuk yang terdiri dari Culex 40, Anopheles 5, Armigeres 1. Jam 22.00-24.00 merupakan waktu akitivitas tertinggi nyamuk yang diperoleh dari data jumlah tangkapan nyamuk tertinggi yaitu 48 ekor di kandang I dan 18 ekor di kandang II. Berdasarkan hasil dan pembahasan maka disimpulkan bahwa keragaman nyamuk di
\end{abstract}

*Kosepondensi (corresponding author)

Email: mjnangoy@yahoo.com
Desa Tolok 3 genus Culex, Anopheles, dan Armigeres sementara kepadatan populasi nyamuk tertinggi pada lokasi kandang yang paling dekat dengan rumah peternak serta aktivitasnya tertinggi pada pukul 22.0024.00

Kata Kunci: Nyamuk, Ternak babi, Aktivitas, Kepadatan, Keragaman

\section{ABSTRACT}

\section{MOSQUITOS}

GENERA (CULICIDAE) IN CAGE AS A VECTOR OF JAPANESE ENCEPHALITIS IN PIGS IN THE TOLOK VILLAGE, TOMPASO DISTRICT, MINAHASA DISTRICT This study aims to determine the diversity and density of the population and the time of mosquito activity (Culicidae) in the pig pen. This reserch was carried out in the Tolok Village, Tompaso District, Minahasa Regency for 2 (two) months at 2 (two) cage locations namely cage I (distance I cage withe house less than $10 \mathrm{~m}$ ) and enclosure II (more than $50 \mathrm{~m}$ ). This research uses the observation method by collecting mosquito samples every 2 (two) hours on the light trap placed in each cage. Samples were collected from 18.0006.00, at each location replicated 3 (three) times with an invoice of two weeks, the samples collected are identified and counted. The results showed diversity of cage mosquitoes I and II each found 3 genera namely Culex, Anopheles, and Armigeres. Population density of cage I was found 128 individual mosquitoes consisting of Culex 104 tails, Anopheles 20 tails, and Armigeres 4. Cage II found 46 mosquitos 
individuals consisting of Culex 40, Anopheles 5, Armigeres 1. Hours 22.0024.00 is the highest time of mosquito activity obtained from the highest number of mosquito catches, which were 48 in cage I and 18 in cage II. Based on the results and discussions, it was concluded that mosquito diversity in the Tolok Village 3 genus Culex, Anopheles, and Armigeres while the highest mosquito population density was at the cage location closest to the breeder house and its activity was highest at 22.00-24.00.

Keyword: Mosquito, pig livestock, activity, density, diversity

\section{PENDAHULUAN}

Nyamuk adalah agent pembawa penyakit yang ditularkan lewat gigitan nyamuk dari ternak babi satu ke ternak babi lain dan kerugian yang ditimbulkan oleh nyamuk yaitu kerusakan kulit, penurunan produktivitas litter zise, babi betina sedang bunting terinfeksi virus Japanese Encepalitisdapat terjadi abortus dan mumifikasi, pada babi pejantan terjadi pembendungan testes, pengerasan pada epididimis, serta menurunnya libido dan media transmisi penyakit terhadap manusia yang bersifat zoonosis (Sendow, 2005). Ternak babi merupakan reservoar penyakit dari Japanese Encephalitis yaitu sebagai sumber penularan penyakit. Pola pemeliharaan yang berada di Desa Tolok, kandang dan pemukiman sangat berdekatan memungkinkan terjadi penularan virus Japanese Encephalitis yang potensial dari ternak babi ke manusia. Sulawesi Utara diketahui merupakan daerah endemik dari virus Japense Encephalitis karena memiliki populasi ternak babi 418. 803 ekor sekitar $30 \%$ dari jumlah populasi yang ada di Minahasa yaitu 126, 157 ekor. Sehingga dilakukan penelitian yang berjudul "Genera nyamuk (Culicidae) dalam kandang ternak babi di Desa Tolok, Kecamatan Tompaso, Kabupaten Minahasa" yang ada di Desa Tolok. Akibat serangan virus Japanese Encephalitistersebut ternak babi mengalami penurunan produktivitas akibat abortus dan mumifikasi. Berdasarkan data BPS (2017), data populasi ternak babi yang ada di Sulawesi Utara 418,803 ekor sekitar 5\% dari jumlah populasi ternak babi yang ada di Indonesia yaitu 8.542.488 ekor.

\section{MATERI DAN METODE PENELITIAN}

\section{Waktu dan Tempat Penelitian}

Penelitian ini dilaksanakan selama 2 bulan (September-Oktober) Tahun 2018 di lokasi kandang ternak babi desa Tolok Kecamatan Tompaso Kabupaten Minahasa Sulawesi Utara. Penelitian lapangan meliputi penetapan lokasi pengambilan sampel nyamuk sedangkan penelitian laboratorium yaitu identifikasi di lakukan di Laboratorium Satwa Liar dan Endemik Fakultas Peternakan Universitas Sam Ratulangi. 


\section{Alat dan Bahan}

Alat yang digunakan dalam penelitian ini adalah Light Trap atau perangkap cahaya, sarung tangan (handskun), botol pembunuh (killing bottle), botol sampel, lup, kamera digital, alat tulis, kertas, labeling buku identifikasi ektoparasit, baju lab, kain selubung. Bahan yang dipakai dalam penelitian ini adalah cairan kloroform.

\section{Teknik Pengambilan}

Untuk teknik pengambilan data nyamuk menggunakan alat Light trap (perangkap cahaya) yang dipasang pada 2 lokasi kandang babi Desa Tolok, kemudian tiap 1 lokasi kandang dipasang 2 unit Light Trapyang dilakukan mulai pukul 18.00 (6 sore)- pukul 06.00 (6 pagi) yang diulang sebanyak 3x ulangan setiap lokasi dan setiap 2 jam kain selubung yang dipasang kemudian diganti dengan kain selubung yang baru selanjutnya kain selubung yang berisikan nyamuk dipisahkan dan diberi label berdasarkan waktu pengambilannya dan di identifikasi di Laboratorium Satwa Liar dan Endemik Fakultas Peternakan Universitas Sam Ratulangi.

\section{Prosedur Penelitian}

\section{Penentuan Lokasi Kandang}

Kandang I. Jarak antara kandang dengan rumah kurang dari 10 meter, dalam

kandang I memiliki 6 petak kandang dan di sekitar kandang ternak babi juga terdapat kandang ternak ayam buras dan ternak bebek. Populasi ternak babi yang berada di dalam kandang berjumlah 15 ekor teridir dari 2 ternak babi betina dewasa, 3 ternak babi pejantan yang dijadikan sebagai pembibit dan 10 ekor ternak babi berumur 38 bulan.

Kandang II. Jarak antara kandang II dengan rumah lebih dari 50 meter dari pada kandang I, kandang yang berada di lokasi II memiliki 20 petak kandang dari 20 petak kandang hanya beberapa petak kandang saja yang terisi ternak babi, disekitar kandang II ternak babi terdapat vegetasi yang banyak terdapar pepohonan yang lebat dan terdapat rumput liar serta populasi ternak babi yang ada di kandang I berjumlah 50 ekor terdiri dari 5 ternak babi betina dewasa, 25 ekor ternak babi sekitar 2 minggu, 20 ekor ternak babi umur 9-12 bulan.

Penelitian yang dilakukan Upik et al. (2011), nyamuk yang tertangkap menggunakan Ultra violet Light Trap sebanyak dua perangkap cahaya yang dipasang selama 12 jam sejak pukul 18.0006.00, tiap 2 jam kurungan perangkap nyamuk diambil dan diganti dengan yang kosong kemudian dibunuh dengan menggunakan kloroform dan dipindahkan dalam tabung plastik yang dilengkapi label catatan lokasi waktu. Nyamuk yang 
tertangkap yaitu Aedes, Culex, Anopheles, Armigeres dan Manzonia.

\section{Pengambilan Sampel}

\section{Identifikasi}

Nyamuk yang tertangkap dimasukkan ke dalam botol pembunuh/killing bottle yang berisi kapas yang sudah ditaruh cairan kloroform, diberi label tanggal penangkapan, ulangan, jam, identifikasi dengan menggunakan alat digital lup sebesar 1600x pembesaran.

\section{Tabulasi Data}

Berdasarkan famili atau genus, Waktu pengambilan dan Ulangan, Lokasi kandang, Ragam nyamuk.

\section{HASIL DAN PEMBAHASAN}

\section{Kondisi Kandang I}

Berdasarkan kondisi kandang I di Desa Tolok dekat dengan daerah persawahan yang jaraknya 4-6 meter dari lokasi kandang, kandang berada di lokasi pemukiman, sekitaran kandang I terdapat ternak unggas (ayam dan bebek). Kebersihan kandang I lebih kotor, kurang pencahayaan, tidak tersedia saluran pembuangan air, tidak ada tempat pembuangan kotoran ternak babi dan pembersihan kotoran tidak teratur. Terdapat tempat perkembangbiak dan perindukan nyamuk seperti genangan air kotor dan bersih, drum berisikan air, lubang yang berwarna gelap dan gantungan baju.

\section{Aktivitas Nyamuk}

Nyamuk Culex aktif malam hari, memilki kebiasaan menggigit manusia dan hewan pada malam hari. Waktu menggigit Culex beberapa jam setelah matahari terbenam hingga sebelum terbit yaitu, pukul 01.00-02.00 adalah puncak aktivitas menggigit nyamuk Culex (Tiawsirisup, 2006) oleh sebab itu nyamuk Culex sering disebut hewan nocturnal. Culex mempunyai sifat antropozoofilik, aktivitas menghisap darah pada malam hari dan luar rumah (Sukendra, 2016). Ramadhani et al (2010) mengatakan, bahwa nyamuk Culex kadang di sembarang tempat untuk berkembangbiak yaitu air kotor, genangan air, dalam rumah (perabotan rumah tangga), di luar rumah (kandang), got terbuka dan saluran pipa, sedangkan Ambarita et al. (2011) menjelaskan, bahwa nyamuk Anopheles berkembangbiak di tempat yang tergenang air kotor dan bersih, genangan air, selokan terbuka, bendungan, rawa-rawa dan empang ikan. Sukendrai (2016) mengatakan juga bahwa Culex bisa berkembangbiak di dalam rumah maupun luar rumah yaitu seperti bak mandi, dalam toilet, gentong air, ember, drum, kaleng bekas, pot bekas, pot tanaman hias, lubang pohon dan pelepah-pelepah pohon. 


\section{Kondisi Kandang II}

Keberadaan kandang II dekat dengan tanaman jagung, tanaman kelapa dan terdapat rawa, sawah jauh dari pemukiman, sekitaran kandang II tidak terdapat ternak lain selain ternak babi. Kebersihan kandang II lebih baik bandingkan dengan kandang I, adanya saluran air, tempat pembuangan kotoran dan pembersihan kotoran hampir selalu dilakukan setiap saat. Kurang terdapat genangan air kotor dan bersih, drum berisikan air, tidak ada gantungan baju yang menjadi tempat dan perkembangbiak dan perindukan nyamuk.

Pada kandang II nyamuk yang tertangkap ada Culex. Anopheles, Armigeres yang lebih sedikit dibandingkan kandang I, walaupun jumlah populasi babi lebih banyak. Hal ini dibatasi oleh kondisi kandang yang relatif lebih bersih, penerangan cukup, tidak ditemukan genangan air sebagai tempat perindukan nyamuk. Ditemukan areal persawahan sekitar kandang II yang cocok untuk perindukan nyamuk Culex sebagai potensial penularan Japanese Encephalitis di kandang II ke manusia masih dimungkinkan walau jarak kandang dengan rumah 750 meter, tetapi jarak terbang nyamuk berkisar 200400 meter (Majawati, 2014).

Nyamuk Anopheles yang di dapatkan pada kandang II terdapat 5 ekor. Berbeda dengan nyamuk Culex, nyamuk Anopheles memiliki sifat Antropozoofilik. Akan tetapi nyamuk Anopheles lebih cenderung Zoofilik yang lebih memilih menyukai darah hewan (Sopi dan Muhammad, 2014). Berdasarkan genus nyamuk Anopheles memiliki perbedaan waktu menghisap darah seperti Anopheles sundaicus pada waktu dini hari jam 22.00-01.00 WIB (Ariati et al, 2008). Pada jam 21.00-03.00 WIB merupakan nyamuk Anopheles maculatus dan pada jam 23.00-05.00 WIB Anopheles barbirostris (Yudhastuti, 2008).

Nurmaini (2003) mengatakan bahwa nyamuk Anopheles berbagai-bagai macam genus dan juga terdapat berbagai-bagai macam karakteristik tempat perkembangbiak dari nyamuk Anopheles seperti menyukai tempat berkembangbiak yang secara langsung dengan sinar matahari, air payau, dan berkembangbiak di air yang tidak mengalir.

Menurut Lestari et al. (2016) tempat perindukan atau yang menjadi habitat nyamuk Anopheles kolam bekas kurungan ikan, lagoon, rawa-rawa, kubangan kerbau, tambak dan sungai. Menurut Tallan (2016) yang meneliti tentang karakteristik habitat perkembangbiak vektor filariasis menjelaskan bahwa nyamuk Culex, Anopheles, dan Armigeres yaitu semaksemak, kandang ternak dan pakaian yang digantung adalah tempat peristirahatan dari ke 3 genus tersebut agar terhindar dari sinar matahari. 
Genus nyamuk di dalam kandang ternak babi

Penelitian yang dilakukan di Desa Tolok berdasarkan 2 lokasi kandang dan nyamuk yang paling banyak tertangkap adalah Culex 144, Anopheles 25, Armgieres 5. Berbagai macam nyamuk terdapat berbagai macam karakteristik atau sifat nyamuk, nyamuk Culex sering disebut sebagai hewan nocturnal yang mempunyai sifat antropozoofilik aktivitas menghisap darah pada malam hari (pada manusia) dan di luar rumah (menghisap darah pada ternak). Nyamuk Anopheles memiliki sifat yang sama seperti nyamuk Culex yaitu Antropozoofilik tetapi nyamuk Anopheles lebih cenderung menyukai darah hewan (Zoofilik).

\section{Gambar 1 Diagram nyamuk dalam kandang I.}

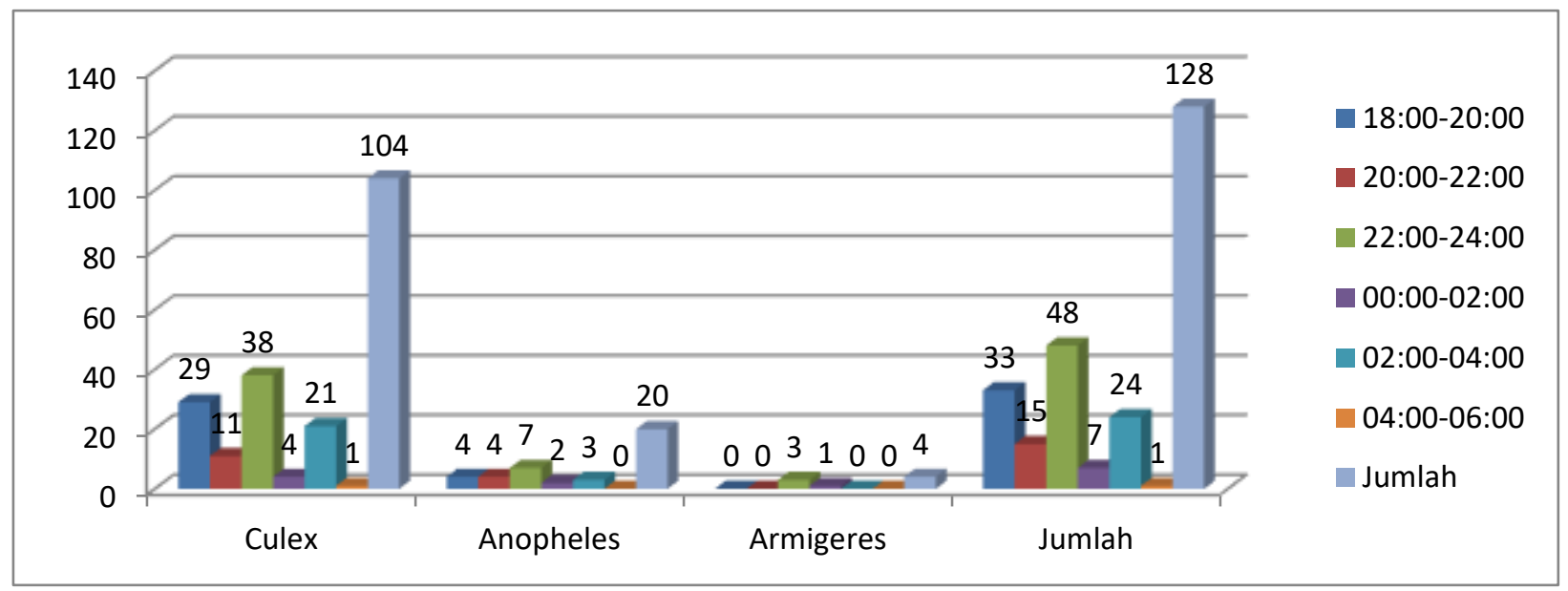

Jumlah keseluruhan nyamuk yang tertangkap yaitu Culex 144, Anopheles 25, Armigeres 5

\section{Gambar 2 Diagram Nyamuk dalam Kandang II}

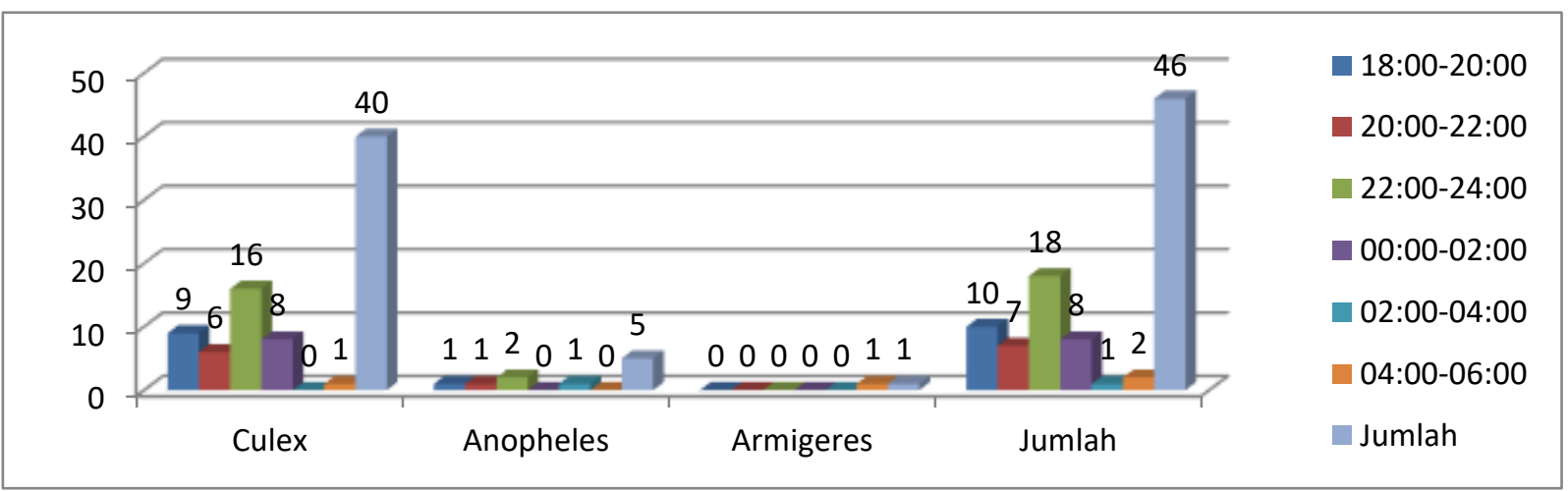


Berdasarkan gambar 1 diagram nyamuk dalam kandang 1 didapatkan hasil penelitian nyamuk yang banyak tertangkap di kandang I adalah nyamuk Culex 104, Anopheles 20, Armigeres 4. Jumlah nyamuk Culex paling banyak pada jam 22.00-24.00 (38 ekor), Anopheles (7 ekor), Armigeres (3 ekor). Jumlah kepadatan yang didapatkan menggambarkan aktivitas nyamuk yang berada disekitar kandang I. Sedangkan penelitian yang dilakukan Upik et al. (2011) didapatkan pada lokasi I jam 22.00-24.00 (167 ekor), lokasi II (3742) dengan genus paling banyak yaitu Culex, Anopheles dan Armigeres. Hal ini sesuai dengan penelitian yang ada di desa Tolok Kecamatan Tompaso Kabupaten Minahasa.

Berdasarkan gambar 2 diagram nyamuk dalam kandang 2 didapatkan hasil penelitian nyamuk yang paling banyak tertangkap di kandang II adalah nyamuk Culex 40, Anopheles 5, Armigeres 1. Jumlah nyamuk Culex paling banyak pada jam 22.00-24.00 (16 ekor), Anopheles (2 ekor), Armigeres (tidak ada). Jumlah kepadatan yang didapatkan menggambarkan aktivitas nyamuk yang berada disekitar kandang II.

\section{Jarak kandang dengan rumah terhadap kepadatan nyamuk}

Jarak kandang I dengan rumah kurang dari 10 meter dengan jumlah nyamuk yang tertangkap 128 ekor. Culex 104 ekor, Anopheles 20 ekor, Armigeres 4 ekor.
Sanitasi kandang yang berada di kandang I kurang diperhatikan. Vegetasi kandang I terdapat tanaman bunga yang menjadi sumber makanan nyamuk jantan, sedangkan untuk nyamuk betina yang menjadi sumber makanan adalah darah ternak babi yang berada di kandang I digunakan untuk pematangan telur. Tersedianya tempat perkembangbiak dan perindukan bagi nyamuk seperti terdapat genangan air kotor dan bersih, drum, gantungan baju dan lubang berwarna gelap. Hal ini memungkinkan penularan virus Japanese Encephalitis terhadap penghuni rumah (manusia). Jarak kandang II dengan rumah lebih dari 50 meter dengan jumlah nyamuk yang tertangkap 46 ekor. Culex 40, Anopheles 5, Armigeres 1. Sanitasi yang berada di kandang II sangat diperhatikan. Vegetasi kandang II dekat dengan daerah persawahan, rawa, tanaman kelapa, padi, dan jagung. Pada waktu penagkapan jumlah nyamuk yang didapatkan lebih sedikit dibandingkan kandang I, karena pada kandang II kurang tersedia tempat perkembangbiak dan perindukan bagi nyamuk.

\section{KESIMPULAN}

Keragaman nyamuk di Desa Tolok terdapat 3 genus Culex, Anopheles, dan Armigeres, sementara kepadatan populasi nyamuk tertinggi pada lokasi kandang yang 
paling dekat dengan rumah peternak serta aktivitasnya tertinggi pada pukul 22.0024.00

\section{DAFTAR PUSTAKA}

Ambarita, P.S., Y. Taviv, D. Purnama, Betriyon, I.R. Pahlepi, A. Saikhu. 2011. Beberapa aspek binomik Anopheles maculatus dan Anopheles leucosphyrus di perkebunan kopi daerah endemis malari Kabupaten Oku Selatan. Jurnal Ekologi Kesehatan 10(4): 229-238

Badan Statistik Peternakan. 2018. Populasi ternak babi di Sulawesi Utara. https://minahasakab.bps.go.id/stattict able/2017/06/14/203/populasi-ternakmenurut-kecamatan-dan-jenis-ternakdi-kabupaten-minahasa-2017.html, Diakses pada tanggal 15 Mei 2019

Lestari, S., Adrial, R. Rasyid. 2016. Identifikasi nyamuk anopheles sebagai vektor malaria dari survei larva di kenagarian sungai pinang Kecamatan Koto XI Tarusan Kabuapten Pesisir Selatan. Jurnal Kesehatan Andalas 5(3): 657-659

Majawati, S.E. 2014. Bionomik Anopheles barbirostris penular malaria. Jurnal Kedokteran Meditek UKRIDA 5(3): 298-300

Ramadhani, T., Soeyoko, S. Sumarni. 2010. Culex quinquifasciatus sebagai vektor utama filariasi limfatik yang disebabkan W.Bancrofti di Keluruhan Pabean Kota Pekalongan. Jurnal Ekologi Kesehatan 9(3): 1303-1310
Sendow, I. 2005. Perkembangan Japanese Encephalitis di Indonesia. Jurnal Wartazoa 15(3).

Sopi, I.I.P.B dan K. Muhammad. 2014. Bionomik anopheles di Desa Konda Maloba, Kecamatan Katikutana Selatan. Kabupaten Sumba Tengah, Provinsi NTT. Jurnal Ekologi Kesehatan 13(3): 240-254

Sukendrai, M.D dan A.M. Shidqon. 2016. Gamabaran perilaku menggigit nyamuk Culex sp, sebagai vektor penyakit filariasis wuchereria bancrofti. Jurnal Pena Medika 6(1): 19-33

Tallan, M.M, dan F. Mau. 2016. Karakteristik habitat perkembangbiak vektor filariasis di Kecamatan Kodi Balaghar Kabupaten Sumba Barat Daya. Jurnal Penelitian Tular penyakit vektor 8(2): 55-56

Tiawsirisup, S. dan S. Nithiuthai. 2006. Vector competence of aedesaegyti (L.) and Culex quinquifasciatus (Say) for Dirofilari imitis (Leidy). Southeast Asian J.Trop Med Public Health 37(3): 111-112

Upik, K.H., S. Soviana, T. Syafriati. 2011. Ragam jenis nyamuk di sekitar kandang babi dan kaitannya dalam penyebaran Japanese Encephalitis. Jurnal Veteriner Desember 12(4): 326-342

Yudhastuti, R. 2008. Gambaran factor lingkungan daerah endemis malaria di daerah berbatasan (Kabupaten Tulung Agung dengan Kabupaten Trenggalek). Jurnal Kesehatan Lingkungan 4(2):9-12 